\title{
THE UTILITARIAN THEORY OF EQUALITY BEFORE THE LAW*
}

\author{
William E. Conklin**
}

\section{INTRODUCTION}

Recent Canadian Supreme Court decisions have reflected a grave uncertainty as to what meaning and scope the Court should give to the terms of the Canadian Bill of Rights. Conceiving the law in a purely Austinian perspective as a system of self-contained rules developed apart from society and its norms, the Court has fallen back upon antiquated legal notions such as Dicey's "rule of law" and upon its own self-image as an "applier" and not a "legislator" of rules. The decisions examining the "equality before the law" provision of the Canadian Bill of Rights reflect the Court's quandaries.

The aim of this essay is to expose the political presuppositions underlying the judicial interpretation of "equality before the law" and to provide an alternative perspective that is more consistent with democratic political theory. More particularly, it will be argued that Canadian and American courts have devised two major tests for defining "equality before the law". These tests are espoused in the utilitarianism of Jeremy Bentham and John Stuart Mill. The essay will conclude by considering a more democratic approach that might be taken towards the Canadian Bill of Rights and especially towards the concept of "equality before the law".

\section{The Utilitarian Notion of Equality Before the LaW}

The utilitarian theory of justice had two branches. ${ }^{1}$ The first concerned the equal or impartial administration and application of the law. This might be called "formal justice". The second branch, which the U.S. courts accepted until the late 1960 's, forbade discriminatory legislative measures unless those measures were reasonably related to the purpose of a

- Research for this paper was stimulated by a Canada Council grant. I am grateful to Andrew Stikuts, a second year student at the time, for assistance in that reseatch and to Marjolijn Doedijns for ber part in the dialogue so necessary in developing the ideas for Part III of the paper.

* Faculty of Law, University of Ottawa.

1 The only writer to raise this distinction is Hugo Bedau, in his Justice and Classical Utiliarianism, in Nomos VI: Justrce 284 (C. Friedrich \& J. Chapman eds. 1963). 
statute. Our Court attempted to apply this test in Burnshine." Equality, under this conception, went beyond formalities: it had substantive moral content, but the content was defined in relation to statutory purpose, which itself depended upon, in Bentham's terminology, "the greatest happiness of the greatest number". Let us examine each of these two branches in turn.

\section{A. The Impartial Administration and Application of the Law}

\section{The Utilitarian Tradition}

John Stuart Mill's chapter "On the Connexion Between Justice and Utility" ' in his Utilitarianism reflects the importance which utilitarian theory placed on impartiality in the administraton and application of the law. "[T]t is, by universal admission", he wrote, "inconsistent with justice to be partial; to show favour or preference to one person over another, in matters to which favour and preference do not properly apply." " Impartiality he defined as "being exclusively influenced by the considerations which it is supposed ought to influence the particular case in hand"." Mill provided two justifications for this impartiality. Both assumed the primacy of "the greatest happiness to the greatest number". First, utility required each individual to be counted once and only once in the calculus of the greatest happiness for the greatest number." Secondly, "society should treat all equally well who have deserved equally well of it" because "it is a duty to do to each according to his deserts, returning good for good as well as repressing evil by evil". That society should treat all equally well was, from society's point of view, "the highest abstract standard of social and distributive justice; towards which all institutions, and the efforts of all virtuous citizens, should be made in the utmost possible degree to converge"."

Another utilitarian, Sir James Fitzjames Stephen, " attacked Mill for having tried to give some moral content to the notion of equality. Stephen emphasized that justice meant formal equality, in the procedural sense of the impartial administration of the laws. As he wrote:

It appears to me that the only shape in which equality is really connected with justice is this-justice presupposes general rules, legal or moral, which are to be applied to particular cases, by those who are in the position of

2 Regina v. Burnshine, [1974] 4 W.W.R. 49, 25 C.R.N.S. 270 (S.C.C.).

'J. S. MnL, Utilltarianism, in Essentul Works of JoHn Stuart Mrle ch. 5, at 183 (M. Lener ed. 1971).

IId. at 230.

Id. at 230-31.

Id. at 246.

Id.

Stephen, incidentally, was a member of the three person Criminal Law Commission which had drafted a criminal code for England in 1878. The English Draft Code became one of four major sources used by Sir John Thompson in drafting our own first Criminal Code of 1892. See Mewett, The Criminal Law, 1867-1967, 45 CaN. B. REv. 726, at 727, 735 (1967). judges with respect to them. If these general roles are to be maintained at all, it is obvious that they must be applied equally to every particular case which satisfies their terms. The rule, 'All thieves shall be imprisoned, is not observed . . . if it is got applied equally to every person who falls within the definition of a thief, whatever else he may be."

Such important legal scholars as Bracton, ${ }^{10}$ Coke, ${ }^{11}$ Blackstone ${ }^{12}$ and Austin have made formal equality the major component of justice. But it was Dicey "who gave the term its contemporary flavour. Dicey held that "Iegal equality" or "equality before the law" required the same ordinary courts to administer the law without partiality as between governmental officials and ordinary citizens. That is, there should be no special judicial tribunals with special jurisdiction over officials, as in the France of Dicey's time. ${ }^{\text {Is }}$ Furthermore, the ordinary courts should administer the

-J. F. STEPHEN, LmetrTY, EqualtTy, FraternitY 185-86 (R. White ed. 1967).

10 See H. Bracton, 1 Rerum Brtannicarum Medn Aevi Scruptores: Crronicles and Memorials of Great Britany and Ireland duRno the Middle ages 39-41 (T. Twiss ed. 1964):

But the king himself ought not to be subject to man, but subject to God and to the law, for the law makes the king. Let the king, then, attribute to the law what the law attributes to him, namely dominion and power, for there is no king where the will and not the law has dominion; and... he ought to be under the law, since he is the vicar of God .. +; for the true mercy of God ... chose this way in preference to all others, as if to destroy the work of the devil he should use not the vigor of his power, but the reason of his justice, and so he was willing to be under the Iaw, that he might redeem those who were under the law, for he was not wrilling to use his strength, but his reason and judgment.

11 See, e.g., Dr, Bonham's Case, 8 Co. Rep. 113b, 77 E.R. 646 (K.B. 1610);

Proclamations, 12 Co. Rep. 75, 77 E.R. 1352 (K.B. 1610).

1 See, e.g., EmLlich's Blacistone 64 (J. Ehrlich ed. 1959):

The prineipal duty of the king is, to govern his people according to law. The king ought not to be subject to man, but to God, and to the law; for the law maketh the King. Let the King therefore render to the law, what the law has invested in him with regard to others; dominion, and power: for he is not truly king, where will and pleasure rules, and not the law. The King also hath a superior, namely God, and also the Iaw, by which nd: he was made a King.

Political, therefore, or eivil, liberty, which is that of a member of society, is no other than natural liberty so far restrained by human laws as is necessary and expedient for the general advantage of the public.

-...

This spirit of liberty is so deeply implanted in our constitution, and rooted even in our very soil, that a slave or a negro, the moment he lands in England, falls under the protection of the law's, and so far becomes a freeman; though the master's right to his service may posstbly still continue. (Id. at 44-45; emphasis added.)

13. See, e.g., J. Austin, 1 The Province of JuRusprudence Determined 235-36 (2d ed. 1861, reprinted 1970).

is See A. DiceY, AN INTRoduction to THE STUbY of the LAW of the ConstrTUTnON (10th ed., reprinted 1973). Dicey considered "equality before the law" synonymous both with "legal equality" (id. at 193) and "the equal subjection of all classes to the ordinary law . . . administered by the ordinary law courts". Id. at 202.

is $l d$. at 195 . 
same law universally to all classes, without being influenced by political or economic privilege. ${ }^{\text {is }}$

\section{The Canadian Judiciary's Application of the Test}

It is unnecessary in this essay to review at length the several Supreme Court decisions which reflect the judiciary's recognition and emphasis of formal equality. The earliest case was the reference Re Exemption of U.S. Forces from Proceedings in Canadian Criminal Courts, ${ }^{\text {"I }}$ in which the Court held that a member of the U.S. armed forces was subject to the jurisdiction of Canadian criminal courts unless he committed an offence on board a U.S. ship or in a military camp, or unless he committed an offence against another American soldier or sailor. Chief Justice Duff adopted Dicey's "fundamental constitutional principle" that "the soldiers of the army of all ranks are not, by reason of their military character, exempt from the criminal jurisdiction of the civil (that is to say non-military) courts of this country"., "

The notion of formal equality was also at the root of the infamous Roncarelli v. Duplessis, 10 in which the Supreme Court held that a public official (Duplessis) was personally liable for acts done without legal justification. Duplessis had argued that, as Attorney General and Premier, he could suppress and prevent crimes "by instituting legal proceedings" and "by other methods"," such as ordering the Quebec Liquor Commission to cancel a liquor licence, even though he had absolutely no legal authority to intervene. Justices Martland, Abbott and Rand held that such an argument was "completely alien to the legal concepts applicable to the administration of public office in Quebec, as well as in the other provinces of Canada"." As Mr. Justice Rand explained: "that an administration according to law is to be superseded by action dictated by and according to the arbitrary likes, dislikes and irrelevant purposes of public officers acting beyond their duty, would signalize the beginning of disintegration of the rule of law as a fundamental postulate of our constitutional structure"."

Similarly, the Diceyan concept of formal equality played a very important part in the Supreme Court's examination of the Lavell case. "2 Section

${ }^{16}$ Id. at 193. Legal equality meant that "every man, whatever be his rank or condition, is subject to the ordinary law of the realm and amenable to the jurisdiction of the ordinary tribunals" (emphasis added). Dicey also wrote that legal equality meant "the universal subjection of all classes to one law administered by the ordinary courts". Id. (emphasis added). For example, see id. at 193-94, 301.

"1 [1943] S.C.R. 483, 80 C.C.C. 161, [1943] 4 D.L.R. 11 .

II Id. at 490,80 C.C.C. at 165 , [1943] 4 D.L.R. at 14 .

1"[1959] S.C.R. 121, 16 D.L.R. (2d) 689 .

"Quoted by Martland J., id. at 155, 16 D.L.R. (2d) at 741

21 ld., 16 D.L.R. (2d) at 741 (Martland F.). See also id. at 158, 16 D.L.R. (2d) at 744 (Martand J.); id. at 184, 16 D.L.R. (2d) at 730 (Abbot J.); id. at 142, 16 D.L.R. (2d) at 706-707 (Rand J.).

${ }^{23}$ Id. at 142, 16 D.L.R. (2d) at 706-707.

${ }^{23}$ See Attorney General of Canada v. Lavell, [1974] S.C.R. 1349, at 1365-66, 23 C.R.N.S. 197, at 211, 38 D.L.R. (3d) 481, at 494-95 (1973).
12(1) (b) of the Indian Act ${ }^{34}$ provides that a woman married to a nonIndian is not entitled to be registered as an Indian. The registrar struck Ms. Lavell's name from the Indian register on the grounds that, having married a non-Indian, she was not entited to be registered as an Indian. The Supreme Court overruled the Federal Court of Appeal's decision that section 12(1)(b) had been inconsistent with the "equality before the law" provision of the Canadian Bill of Rights; it did so because an Indian male would not lose Indian status upon marriage to a non-Indian woman. The Supreme Court understood "equality before the law" in Dicey's sense that "the same law applies to the highest official of government as to any other ordinary citizen"." Mr. Justice Ritchie defined the concept as "equality in the administration or application of the law by the law enforcement authorities and the ordinary courts of the land". " Any alleged inequality in the administration or application of the law must flow "as a necessary result" 23 from the statute.

Thus, "equality before the law" was held in the Re Exemption, Roncarelli and Lavell cases to be directed to procedure only and to have no bearing upon the substantive content of a statute; it was a formal requirement assuring the impartial administration and enforcement of the law before or in the presence of the courts but not guaranteeing any equality in the law itself. According to this conception equality before the law means, as Lord Wright stated, that "all persons are equally subject to the law, though the law to which some are subject may be different from the law to which others are subject". "s To put the matter another way, Parliament, much the same as a testator, may define the object of its bounty as it wishes and according to "public policy" considerations which are beyond judicial scrutiny. In so defining its beneficiaries Parliament does not infringe the rights of persons falling outside its definition.

\section{Weakness of the Test}

So emptied of moral content, this interpretation of equality before the law is suitable for a society of slaves and, to use Mill's words, carries "the most outrageous inequality in the rights themselves". ${ }^{20}$ The most arbitrary forms of racial or religious discrimination would be permissible so long as the discriminatory laws were evenly and consistently administered among individuals belonging to the class against which the discrimination is directed. ${ }^{\text {so }}$ To give equality some substantive content Mill and Bentham turned to the notion of the greatest happiness of the greatest number.

"2 R.S.C. 1970 , c. I-6.

${ }^{25}$ Supra note 23, at 1366,23 C.R.N.S. at 211,38 D.L.R. (3d) at 495.

${ }^{36}$ Id., 23 C.R.N.S. at 212, 38 D.L.R. (3d) at 495 (emphasis added).

${ }^{37}$ Id. at 1372,23 C.R.N.S. at 216, 38 D.L.R. (3d) at 499 (emphasis added).

7" Wright, Liberty and the Common Law, 9 CaMn. L.J. 2, at 4 (1945).

*0 J. S. MuL, Utitirarianism, supra note 3, at 231.

to As John Rawls explains in A Theory of Justice 59 (1971):

Treating similar cases similarly is not a sufficient guarantee of substantive 


\section{B. The Greatest Happiness of the Greatest Number}

\section{The Priority of "Community Interest"}

For Bentham the common end of all laws was happiness. " The utility of any proposed law was measured by its tendency to bring happiness or to diverge from happiness. " Bentham defined happiness as "benefit", "advantage", "pleasure" or "good"." It was possible to determine whether a proposed measure tended to increase happiness by merely adding the sum total of pleasures and subtracting the pains that the enactment would bring to each and every person in the community. " As Bentham himself explained:

[G]overnment is good in proportion as it contributes to the greatest happiness of the greatest number; namely, of the members of the community in which it has place. Rule may therefore come under the denomination of misrule in either of two ways: either by taking for its object the happiness of any other number than the greatest, or by being more or less nnsuccesuful in its endeavours to contribute to the grealest happiness of the greatest number. "

The principle of utility had several consequences for civil liberties. In the first place, the state could make any act a crime so long as to do so would create the greatest happiness for the greatest number. ${ }^{\text {" }}$ Secondly, once

jostice. This depends upon the principles in accordance with which the basic structure is framed. There is no contradiction in supposing that a slave or caste society, or one sanetioning the most arbitrary forms of discrimination, is evenly and consistently administered, although this may be unlikely.

n J. Bentrum, An Introduction to the Princtiples of Morals and Leglistation ch. 3, para. 1 (J. Burns \& $H$. Hart eds. 1970) (hereinafter cited as AN INTRODUCTIONI:

[T] he happiness of the individuals, of whom a community is composed, that is their pleasures and their security, is the end and the sole end which the legislator ought to have in view: the sole standard, in conformity to which each individual ought, as far as depends upon the legislator, to be made to fashion his behaviour.

See also J. Bentrum, A Fragment on Governarent (F. Montague ed. 1891) (hereinafter cited as A FraOMrent]; J. S. MmL, Utilitarianism, supra note 3, at 194 ("pleasure and freedom from pain are the only things desirable as ends" ); J. Ausrnw, supro note 13 , at 264 .

d. BENIthM, AN INTRODUCTON, id. at ch. 1, paras. 2, 6, 7; A FRAGMENT, id. at ch. 1, park 45 .

a J. BenthaM, AN INTRODuction, supra note 31, at ch. 1, para. 3.

$\boldsymbol{u}$ J. Bentrum, $t$. at ch. 1, paras. 4-7.

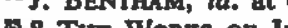

8 The Works of Jeremy BeNTHAM 558 (J. Bowring ed. 1962).

a J. Bentrum, AN InTroduction, supra note 31, at ch. 16, para. 1:

Any act may be an offence, which they whom the community are in the habit of obeying shall be pleased to make one: that is, any act which they shall be pleased to prohibit or to punish. But, upon the principle of utility, such acts alone ought to be made offences, as the good of the community requires should be made so.

Mill was of a similar view:

[T]he admitted functions of government embrace a much wider field than can easily be included within the ring-fence of any restrictive definition, and ... it is hardly possible to find any ground of justification common the state had created a crime, the courts could determine the nature and severity of a sentence by reference to the same standard. ${ }^{27}$ Thirdly, Bentham appears to have used the notion of equality in two very limited senses. Equality meant giving each person's happiness equal weight. * But it also meant "equilibrium"; Bentham wrote that an "equable" punishment was one that accurately balanced the harm done to the individual by the punishment with the harm the criminal had caused the community.

The fourth and most important consequence which utilitarian theory had for civil liberties concerns the utilitarian notion of a right. The utilitarian created a right out of the greatest happiness of the greatest number. A "right" was something that ought to be done: it was a right as opposed to a wrong action." And a right action was one that increased the community's happiness. In this way the "rights" of an individual were conflated with the "felicity calculus" of the "greatest good of the greatest number". That is, whether an injured person had a right depended entirely upon whether his conduct possessed the tendency to add to the greatest happiness of the greatest number. Another of Bentham's followers, John Austin, wrote that despite what "the ignorant and bawling fanatics who stun you with their pother about liberty" say, the "final cause or purpose for which government ought to exist, is the furtherance of the common weal to the greatest possible extent". "1 And government attained this purpose by

to them all, except the comprehensive one of general expediency; nor to limit the interference of government by any universal rule, save the simple and vague one, that it should never be admitted but when the case of expediency is strong.

(J. S. Mil. 3 Collected Worrs 803-804 (J. Robson ed. 1965).)

"J. BeNTHAM, AN INTROduction, supra note 31 , at ch. 15, para. 2; ch. 13, paras. 1-3. Note also his explanation of the defences of consent, infancy, insanity and intoxication, $\ell d$, at ch. 13 , paras. $4 \& 9$.

"Mill attributes to Bentham the dictum "everybody to count for one, nobody for more than one". J. S. MnL, Utilitarianism, supra note 3, at 246 .

3. BentrlaM, AN INTroduction, supra note 31, at ch. 15, paras. 2 \& 3. "Ronald Dworkin examines the "weak" meaning of a right in his Taking Rights Seriously, New York Review of Books, December 17, 1970.

As Bentham himself explained:

Of an action that is conformable to the principle of utility, one may always say either that it is one that ought to be done, or at least that it is not one that ought not to be done. One may say also, that it is right it should be done; at least that it is not wrong it should be done: that it is a right action; at least that it is not a wrong action. When thus interpreted, the words ought, and right and wrong, and others of that stamp, have a meaning; when otherwise, they have none.

(J. Benttiam, AN InTroduction, supra note 31, at ch. 1, para. 10.).

if. Austin, supra note 13, at 242 .

Similarly, when Mill was asked why society ought to protect an individual's rights he responded quite simply: "I can give him no other reason than general utility." J. S. MnI, Utllitarianism, supra note 3, at 238. According to Mill, what gave a right its "character of absoluteness" was nothing more nor less than the psychological feeling that surrounds it. Rights differed from "the more common cases of utility" simply because of the difference in the degree of intensity of feeling for them. That "difference in degree (as is often the case in psychology) becomes a real difference in kind". Id. at 239 . 
conferring such rights and duties upon its subjects "as general utility commends". A right was merely "a simple permission" granted to the subject by the state. The utilitarian's right was, to the individual, a very weak right indeed.

It must be emphasized that utilitarian theory called for restrictions upon liberty and equality whenever such restrictions were reasonably necessary to the community's happiness. As Austin explained: "[S]ince the power of the government is incapable of legal limitation, the government is legally free to abridge their political liberty, at its own pleasure or discretion." ${ }^{2}$ Or, in Mill's words: "All persons are deemed to have a right to equality of treatment, except when some recognized social expediency requires the reverse." " The same held for Mill's notion of liberty. His "one very simple principle" was that "the only purpose for which power can be rightfully exercised over any member of a civilized community, against his will, is to prevent harm to others". " Once the person's conduct prejudicially affected the interests of other persons, society had jurisdiction. The issue then arose whether a restriction of the alleged delinquent's conduct would promote the general welfare. So Mill's famous principle of non-interference with the individual's "inner life" was greatly qualified. "to "Self-regarding virtues" were second in importance to social virtues. Indeed, Mill himself conceded that even freedom of speech lost its immunity from interference when opinions were expressed in circumstances which constituted "a positive instigation to some mischievous act". " Any individual's behaviour may affect another person's interest. Thus, the "inner life" was confined to a narrow sphere indeed. "t

Society could reasonably and justifiably restrict liberty and equality in a wide range of circumstances. This was at least in part because the starting point in assessing the reasonableness of a restriction was the welfare of the majority, not any independent criteria such as liberty or equality. Utilitarian legislation could only be challenged by asserting that more appropriate means could be used to achieve the social welfare. Secondly, utilitarians defined the community's welfare in very vague and wide terms. Bentham defined "the community", for example, as "a fictitious body, composed of the in-

4. J. Austin, supra note 13, at 242.

Id. at 241 .

4J. S. MnL, Utilitarianism, supra note 3, at 247 . An individual would suecumb to the dictates of social expediency presumably because "a human being is capable of apprehending a community of interest between himself and the human society of which he forms a part". Id. at 236.

${ }^{45} \mathrm{~J}$. S. Mill, On Liberty, in Essentual Works of John Stuart Mili 253, at 263 (M. Lerner ed. 1971). (1968).

46. This point is touched on in R. Wolff, The Poverty of Liberalism 21-25

4 J. S. MILL, On Liberty, supra note 45, at 304.

1" Id, at 290. Note Mill's argument that one "may justly incur punishment" by making oneself "a nuisance to other people", c.g. by telling an excited mob that corndenlers are starvers of the poor. Id. at 304. dividual persons who are considered as constituting as it were its members". The interests of this "fictitious body" were what the majority of the legislature said they were. "Mill, who himself loathed the "tyranny of the majority", st acknowledged the open-endedness of a concept capable of accomodating so many interests (as, for example, money, fame, power, music, health, virtue and the like). Pushing the utilitarian thesis to its logical conclusion, Sir James Fitzjames Stephen asserted that governmental coercion of an individual was reasonably justifiable for the purposes of establishing and maintaining religion and morality, altering existing forms of government, and protecting the state itself. ${ }^{\text {st }}$

Even in On Liberty liberty and equality are subordinated to the majority's welfare. ${ }^{\text {ss }}$ In a famous passage Mill gives the following rationale for his belief that mankind is not justified in silencing even one person:

[T] the peculiar evil of silencing the expression of an opinion is, that it is robbing the buman race; posterity as well as the existing generation; those who dissent from the opinion, still mote than those who hold it. If the opinion is right, they are deprived of the opportunity of exchanging error for truth: if wrong, they lose, what is almost as great a benefit, the clearer perception and livelier impression of truth, produced by its collision with
error. $M$

Mill's other arguments for freedom of expression were also based on the community's happiness. In the first place, he argued that to silence a dissenting opinion was to claim infallibility for the opinion of the day. But, since infallibility was impossible, the possibility always existed that the silenced opinion might add something to public knowledge. Secondly, the best government was one capable of synthesizing the opinions of dissenters. Thirdly, whether or not an opinion was useful to society was itself a matter of opinion, "as disputable, as open to discussion, and requiring discussion as much, as the opinion itself". ${ }^{35}$ But there could be "no fair discussion of the question of usefulness, when an argument so vital may be employed
on one side, but not on the other".

Mill's final argument was that free expression was essential for the full development of the individual. Although this would seem to indicate a shift from social happiness to individuality as an uitimate good, Mill was quick to emphasize that individuality was "one of the principal ingredients

19. Benthim, AN INTROduction, supra note 31 , at ch. 1, para. 4

st D. Manning, The Mind of Jeremy Bentriam 78 (1968).

MmL, Essays of Pot, Essay on Bentham, first published in 1838 and reprinted in J. S. ESSAYS OF POLmTS NND CULTURe 77, at 110-113 (G. Himmelfarb ef. 1963).
aj J. F. STEPHEN, supra note 9, at 61. As he explained: "Mmf the

[from compulsion] overbalances the inconvenience of the computsion itself obtained understand how, upon utilitarian principles, the compulsion computsion itself I do not ${ }^{83}$ Mill's father was even less subtle in his subordination of liberty to at 85-86. happiness of the greatest number. See JAMES MHL, EsSAYs on Gover to the greatest

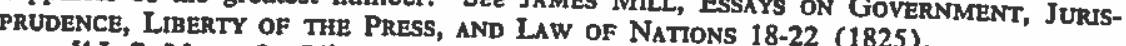
s4. S. MnL, On Liberty, supra note 45, at 269.

${ }^{33}$ Id. at 274 .

st Id. 
of human happiness, and quite the chief ingredient of individual and social progress". ${ }^{\text {st }}$ More precisely, "[in] proportion to the development of his individuality, each person becomes more valuable to himself, and is therefore capable of being more valuable to others. There is a greater fulness of life about his own existence, and when there is more life in the units there is more in the mass which is composed of them", " A spontaneous, creative, fully developed individual had an especially great utility to society "when the opinions of masses of merely average men are everywhere become or becoming the dominant power". "Thus, even John Stuart Mill justified the liberty of the individual by its utilitarian value in achieving social happiness.

\section{2. "Reasonable Classification": Utilitarianism in American Judicial} Reasoning

Utilitarian theory provides an indispensable vantage point for understanding the "reasonable classification" approach toward defining "equal protection of the laws" or "equality before the law". Interestingly enough, not many years after the enactment of the fourteenth amendment, the U.S. courts acknowledged the inadequacy of the "impartiality" or formal justice test for defining "equal protection"." They sought to strike down substantive legislation for reasons similar to those derived from social utility. Now, in Canada, sixteen years after the enactment of the Canadian Bill of Rights, our courts, "legislators " and legal scholars "s are treading the same paths. Let us, therefore, briefly examine the "reasonable classification" test as the U.S. courts have developed it.

One of the earliest U.S. cases applied the test in this manner:

1. The equal-protection clause of the 14th Amendment does not take from the state the power to classify in the adoption of police laws, but admits of the exercise of a wide scope of discretion in that regard, and avoids what is done only when it is without any reasonable basts, and therefore

sf. at 305 .

ad. at 311 .

Id. at 315 .

"Yick Wo v. Hopkins, 118 U.S. 356, at 369, 6 S. Ct. 1064 at 1070 (1886): "[T] the equal protection of the laws is a pledge of the protection of equal laws."

"See Regina v. Burnshine, supra note 2.

a See text between notes 101 and 110 .

almost every Canadian academic who has written on the subject of the Canadian Bill of Rights has advocated the adoption of the "reasonable classification" test to define equality before the law. See, e.g., W. Tarnopolstr, ThR Canadin Bill op Rughrs 307-16 (2d rev, ed. 1975); Kelly, The Bill of Rights, the Indian Act, and Equalioy before the Law: The Need for, and the Development of, a "Reasomableness" Equalit before Test, 2 QuneEN's LJ. 151, at $165 \mathrm{ff}$. (1974); Sanders, The Bull of Rights and Indlan Status, 7 U.B.C. L. REv. 81, at 95, 103 (1972); Bowker, Comment, 8 AlTA. L Rev, 409, at $415 \mathrm{ff}$. (1970); Hogg, Comment, 52 CAN. B. Rev. 263, at 278-80 (1974). Tarnopolsky's unequivocal adoption of the "reasonable classification" test is also set out in his most recent article on the subject, The Supreme Court and the Canadlan Bill of Rights, 53 CaN. B. Rev. 649, at 665 (1975). However, note Professor Gold's adoption of the "suspect doctrine" in his Equality before the law (an annotation to Regina v. Natrall), 20 C.R.N.S. 280, at 288-90 (1973). is purely arbitrary. 2. A classification having some reasonable basis does not offend against that clause merely because it is not made with mathematical nicety, or because in practice it results in some inequality. 3. When the classification in such a law is called in question, if any state of facts reasonably can be conceived that would sustain it, the existence of that state of facts at the time the law was enacted must be assumed. 4. One who assails the classification in such a law must carry the burden of showing that it does not rest upon any reasonabie basis, but is essentially arbitrary. $\mu$

This summary merely begs the question: what is an "essentially arbitrary" classification? Tussman and tenBroek responded in their classic essay that a classification was reasonable if it succeeded in the similar treatment of persons similarly situated. similarly situated, one merely had to look at the purpose of the statute that set up the classification. This "reasonable classification" examination had three important elements: the legislative classification, the statutory purpose, and the relationship between the classification and that purpose.

\section{(a) The Classification}

Once the U.S. Supreme Court established that the "equal protection" clause possessed some substantive content in addition to the notion of impartiality, "it had to resolve the conflict between the need for "equal laws" and the need for special laws. If carried to the extreme, the Court speculated, "equal protection" might require that all persons should be subject to the same substantive laws. On the other hand, the Court believed that legislation was the product of weighing "burdens and benefits". When the legislature provided for the construction of a highway across a county, for example, it was conferring a "benefit" upon car owners but was imposing a "burden" upon all taxpayers. The legislature could not confer such "benefits" and "burdens" without classifying the recipients; thus, given the Court's Benthamite conception of the nature of legislation, discriminatory classifications were inevitable. It was for the courts to determine which discriminatory classifications were unreasonable.

It is already apparent that the "reasonable classification" test does not add much substance to the "equal protection" clause. First, as we have already noticed, the utilitarian conception of legislation as a matter merely of "benefits" and "burdens" leaves little room for the rights of individuals." Secondly, the judiciary, because of its traditional reverence for legislative pronouncements, might well enforce a statute ostensibly making one classification but in effect making a very different one. Let us assume, for ex-

Mindsley v. Natural Carbonic Gas Co., 220 U.S. 61, at 78-79, 31 S. CL 337, at 340 (1911) (emphasis added).

es Tussman \& tenBroek, The Equal Protection of the Laws, 37 CaLIP. L. Rev. 341 , at 346 (1949).

See Yick Wo v. Hopkins, supra note 60.

- See the judgments of Douglas and Jackson, JJ., in Railway Express Agency Inc. v. New York, 336 U.S. 106, 69 S. C.. 463 (1949). 
ample, that 95 per cent of the citizens of the Yukon are Eskimos and that there are very few Eskimos living elsewhere in Canada. Let us also assume that Parliament declares the age of juvenile delinquency to be 18 years except in the Yukon, where it is to be 14 years. Is the classification made in the statute actually what it purports to be? That is, is it directed to "all persons resident in Canada except in the Yukon"? Is not the real classification "all non-Eskimo residents of Canada"?

\section{(b) The Purpose}

The community's interest as represented in the statutory purpose is a given. That is, as in utilitarian theory, the interest of the majority creates and sustains the rights of the individual as embodied in statute. Interestingly enough, almost all students of the "reasonable classification" test have worked within the traditional utilitarian framework and have focused on the classification in its relationship to the statutory purpose, rather than on the actual nature and scope of that purpose. ${ }^{a}$ The consequence is that the test is far weaker, more arbitrary and more complex than commentators have led us to believe.

It is always possible, for example, to define a legislative purpose in such a way that the classification is reasonably related to it; the plain terms of the statute will ustailly suggest a statutory purpose of benefiting or burdening the persons in the identified class." In this way the "reasonable classification" test becomes an unreasonable tautological pursuit. Furthermore, the state can always "by-pass" the test simply by expressly defining the statute's purpose so narrowly that the courts will be obliged to find the classification reasonably related to the purpose.

The several judicial techniques available to determine a statutory purpose make the test arbitrary as well as weak. As Professor Willis argued, the three approaches for determining legislative intent (the "literal", "absurdity" and "mischief" approaches) are all equally valid, and each can lead to a different conclusion. " Contemporary Canadian decisions reflect the

* See, e.g., Tussman \& tenBroek, supra note 57; Karst, Invidious Discrimination: Justice Douglas and the Return of the "Natural-Law-Due-Process Formula", 16 U.C.L.A. L. Rev. 716 (1969); Michelman, Foreword: On Protecting the Poor through the L. Rev. Ouota, 6 Howard L.J. 30 (1960); Bazos, Note, [1973] WIS. L. Rev. 908; Groves, Equal Protection of the Laws in Malaysia and India, 12 AM. J. CoMP. L. 385 (1963); Developments in the Law-Equal Protection, 82 Harv. L. Rev. 1065 (1969); HuangThio, Equal Protection and Rational Classification, [1963] PuB. L. 412; Dembitz, Racial Discrimination and the Milltary Judgment: The Supteme Court's Korematsu and Endo Decisions, 45 Colum. L. Rev. 175 (1945). Cf. Wilson, The Merging Concepts of Liberty and Equality, 12 WASH. \& LEE L. REV. 182 (1965).

${ }^{20}$ This point is developed in an unsigned note entitled Legislative Purpose, Rationality, and Equal Protection, 82 YALE L.J. 123 (1972).

${ }_{7}$ Willis, Statute Interpretation in a Nutshell, 16 CAN. B. Rev, 1 (1938). continued validity of his thesis. ${ }^{n}$ Even if, by a combination of the three approaches, one "purpose" could be obtained, our courts have ample devices to avoid, enlarge or restrict that "purpose". Statutory presumptions are but one example. ${ }^{n}$

This raises the further problem that the test assumes that a statute will possess merely one purpose. This gravely oversimplifies the nature of legislation and the legislative process in a liberal state. Any one enactment may be the outcome of complex, usually conflicting, pressures from both within and without the bureaucracy. ${ }^{14}$ Any one statute may attempt to resolve not just one but several "mischiefs" at the same time.

\section{(c) The "Reasonable Relationship"}

Assuming that one does ascertain the classification and purpose of a statute, how does one determine whether the relationship is a "reasonable" one? Tussman and tenBroek described three situations in which the correspondence between classification and purpose was "unreasonable". ts First, the classification might be under-inclusive; the legislature should have included other persons in the class. Secondly, it could be over-inclusive; the legislature should have excluded some of the persons it has brought within the class. Thirdly, it could be both under- and over-inclusive; the legislature should have included some persons and excluded others. The internment of the Japanese Americans is an instance of the third "unreasonable" relationship. The American Congress' classification of "American citizens of Japanese ancestry" might, however, be considered under-inclusive, because it excluded American citizens of German and Italian ancestry who were arguably under the same suspicion of disloyalty. On the other hand, the classification may have been over-inclusive, because not all Americans of Japanese ancestry were disloyal.

Simple under- or over-inclusiveness does not, however, in itself result in unconstitutionality. The discriminatory classification might still satisfy the "reasonable classification" test if the classification is "supportable by reasoned considerations"." But what constitutes a "reasoned consideration"? As has been forcefully argued elsewhere, " reasonableness is rela-

"For examples of the "literal" approach, see Murray v. W. Vancouver, [1937] 3 W.W.R. 269 (B.C.S.C.); Magor \& St. Mellons Rural Dist. Council v. Newport Corp., [1952] A.C. 189, [1951] 2 All E.R. 839. For an example of the "absurdity" approach, see Regina v. Mojelski, 65 W.W.R. 565 (Sask. 1968), rev'g 60 W.W.R. 355 (Sask. Q.B. 1967). For an example of the "mischicf" approach, see McBratney v. McBratney, 59 S.C.R. 550, [1919] 3 W.W.R. 1000, 50 D.L.R. 132.

" For other examples, see E. DRIEDger, THE Construction of Statutes (1974).

i" See, e.g., S. Walktand, The Legislative Process in Great Britain (1968)

and $R$. Jacrson \& M. Atianson, The Canablan Legislative System (1974).
Tussman \& tenBroek, supra note 65, at 347-53.

"Black, The Lawfulness of the Segregation Decisions, 69 YALE L.J. 421, at 2 (1960).

"Powell, The Unreasonableness of the Reasonable Man, 10 Current Lead Pronlems 104 (1957). 
tive. Thus, one person's reasonableness is bound to be another's unreasonableness. What one segment of society considers reasonable is unreasonable to another; what a former generation considers reasonable is unreasonable to a later. It was once "reasonable", for example, for the U.S. courts to uphold racial segregation." Indeed, it has been argued that the notion of "reasoned elaboration" is itself only one phase-and a passing phase at that-in the evolution of legal academic criticism in North America."

One need not examine the complex philosophical and psychological aspects of the nature of rationality to foresee that the legal requirement of "reasoned considerations" could become the pretext for the imposition of arbitrary value judgments. And such has been the history of the "reasonable classification" test in the U.S. The test itself subtly evolved into a "rational relationship" or "minimum rationality" test, with the direct consequence that the courts virtually abdicated judicial review." Under the latter test the courts developed a very strong presumption that a statute satisfied the constitutional requirement of "equal protection"." With the exception of classifications affecting racial minorities and first amendment rights, the U.S. courts would accept any probable reason for an under- or over-inclusive classification. More specifically, the courts merely asked whether "any state of facts reasonably may be conceived to justify [the classification]". "

One can understand, therefore, why it was so easy for the U.S. Supreme Court to sustain the constitutionality of all but one state statute challenged between 1937 and 1970 on "reasonable classification" grounds under the "equal protection clause". " The courts invariably assumed that a state legislature had legitimate reasons for the classification." precluded petitioners from raising any arguments on the very issue of reasonableness itself. Furthermore, even where the court did not adopt that assumption, the most probable "reasoned consideration" was naturally conceived to be the one that supported the statute's constitutionality. The courts were especially prone to give the legislature the benefit of the doubt

T" E.g., Gong Lum v. Rice, 275 U.S. 78, 48 S. Ct. 91 (1927).

White, The Evolution of Reasoned Elaboration: Jurtsprudential Criticism and Social Change, 59 VA. L. Rev. 279 (1973).

- Goodpaster, The Constitution and Fundamental Rights, 15 ARuz. L. REv. 479, at 486 (1973).

1 See, e.g., McDonald v. Bd, of Election Comm'rs, 394 U.S. 802, at 809, 89 S. Ct. 1404, at 1408 (1969).

acGowan v. Maryland, 366 U.S. 420, at 426, 81 S. Ct. 1101, at 1105 (1961). See also McDonald, supra note 81 , at 809 , $89 \mathrm{~S}$. Ct. at 1408; Flemming v. Nestor, 363 U.S. 603 , at $611-12,80 \mathrm{~S}$. C. 1367 , at $1372-73$ (1960).

a Richard Fielding cites the single anomalous case as Morey v. Doud, 354 U.S. 457, 77 S. Ct. 1344 (1957): Fielding, Fundamental Personal Rights: Another Approach to Equal Protection, 40 U. CHD. L. Rev. 807, at 811 (1973).

MThis point is made in an unsigned note entitled Potentialities of Equal Protection as an Implement of Judicial Review, 29 IND. L.J. 189, at $203 \mathrm{ff}$. (1954).

a Developments in the Law-Equal Protection, supra note 69, at 1078. in emergency conditions. "Finally, it was sufficient that an under-inclusive classification only partially remedied the alleged mischief leading to the enactment of the statute." So long as a classification had "some reasonable basis", the court would sustain it, even though "it [was] not made with mathematical nicety" or "in practice ... results in some inequality". "

These latter limitations on the "reasonable classification" approach are apparent upon an examination of the archetypal decision defining the test. At issue in Railway Express Agency Inc. $v$. New York " was a traffic regulation which had provided:

No person shall operate ... an advertising vehicle; provided that nothing herein contained shall prevent the putting of business notices upon business delivery vehicles, so long as such vehicles are engaged in the usual business or regular work of the owner and not used merely or mainly for advertising.

The Agency was convicted and fined for being in violation of this regulation. Counsel for the Agency argued before the U.S. Supreme Court that the regulation violated the "equal protection" clause, because the classification was under-inclusive. It was argued that persons who advertised their own products on their own trucks caused just as much traffic dislocation as persons whose trucks carried general commercial advertisements. Therefore, the classification was unrelated to the statutory purpose of traffic safety. In response to this argument $\mathrm{Mr}$. Justice Douglas, speaking for the Court, held that the legislature "may well have concluded" that the one group did not present the same traffic problem as the other. ${ }^{*}$ The Supreme Court believed that the Court lacked the "degree of omniscience" " necessary to determine whether both groups created the same amount of traffic dislocation. Furthermore, the Court felt that it should resolve the issue of "equal protection" by "practical considerations based on experience rather than by theoretical inconsistencies". " Finally, it was "immaterial" that the legislature failed to eliminate other, more serious distractions to the traffic. In Mr. Justice Douglas' words: "It is no requirement of equal protection that all evils of the same genus be eradicated or none at all." "s

(d) The Burnshine Case: the "Reasonable Classification" Test in the Canadian Supreme Court

The emptiness of the "reasonable classification" test was apparent in

"See, e.g., Hiribayashi v. United States, 320 U.S. 81, 63 S.Ct. 1375 (1943); Korematsu v. United States, 323 U.S. 214, 65 S.CL 193 (1944),

$"$ Williamson v. Lee Optical of Oklahoma, 348 U.S. 483, 75 S.Ct. 461 (1955); West Coast Hotel Co. v. Parrish, 300 U.S. 379, 57 S.Ct. 578 (1937).

"Lindsley v. Natural Carbonic Gas Co., supra note 56, at 78, 31 S.Ct. at 340 .

a36 U.S. 106, 69 S.Ct. 463 (1949).

- Id. at 110, 69 S.Ct, at 465 .

Id.

$m I d$.

Id., 69 S.C., at 466. 
the Canadian Supreme Court decision of Burnshine. ${ }^{\text {at }}$ Burnshine, a seventeen-year-old male, was charged with causing a disturbance in a public place in the city of Vancouver. The Criminal Code ${ }^{2 s}$ provided for a maximum sentence of a 500 dollar fine, or 6 months imprisonment, or both. However, upon conviction, Burnshine was sentenced to a term of three months definite and two years less one day indeterminate, pursuant to section 150 of the Prisons and Reformatories Act." Section 150 provided that

Every court in the Province of British Columbia, before which any person apparently under the age of twenty-two years is convicted of an offence against the laws of Canada, punishable by imprisonment in the common gaol for a term of three months, or for any longer term, may sentence such person to imprisonment for a term of not less than three months and for an indeterminate period thereafter of not more than two years less one day

(a) in the case of a male person apparently under the age of eighteen years, in Haney Correctional Institution,

(b) in the case of any other male person to whom this section applies, in Oakalla Prison Farm or in New Haven, or

(c) in the case of a female person to whom this section applies, in a place designated by the Lieutenant Governor for such female persons instead of the common gaol of the county or judicial district where the offence was committed or was tried, and such person shall thereupon be imprisoned accordingly until be is lawfully discharged or paroled pursuant to section 151 or transferred according to law, and shall be subject to all the rules and regulations of the institution as may be approved from time to time by the Lieutenant Governor in that behalf.

Counsel argued that under section 150 of the Prisons and Reformatories Act Burnshine was subject to a greater punishment than other Canadians who committed the same crime and that he was, therefore, denied equality before the law. Mr. Justice Martland, who delivered the majority judgment, held that the definition of that concept was frozen at what it was at the time of the enactment of the Canadian Bill of Rights. The consequence was that he applied the first branch of the utilitarian theory of equality (the impartial administration of the law or formal justice). At the beginning and end of his reasons for judgment, however, Martland appeared to hold that the alleged discriminatory classification of persons under twenty-two years in British Columbia was reasonably related to the purpose of section 150 . The statutory purpose, according to Mr. Justice Martland, was "the reform and training of young offenders". "7 The classification was reasonably related

"Supra note 2. Some Canadian commentators have interpreted The Queen v. Drybones, [1970] S.C.R. 282, 9 D.L.R. (3d) 473 (1969); Attorney General of Canada v. Lavell, supra note 23; and the Court of Appeal decision in Canard v. Attorney General of Canada, [1972] 5 W.W.R. 678, 30 D.L.R. (3d) 9 (Man.) (Dickson J.A.), as applying the "reasonable classification" test. See, e.g., W. TARNOPOLSKY, THE CaNADLAN BILI OF RIGHTS, supra note 63, at 307-308; Tarnopolsky, The Canadlan Bill of Rights and the Supreme Court Decisions in Lavell and Burnshine: A Retreat from Drybones to Dicey?, 7 OTTAwa L. Rev. 1 (1974); Bowker, supra note 63; Kelly, supra note 63; Sanders, supra note 63, at 95-105.

is R.S.C. 1970, c. C-34, 171, as amended S.C. 1972 c. 13, 11 ,

in R.S.C. 1970 , c. P-21.

in Supra note 2, at 52, 25 C.R.N.S. at 273. to that purpose because British Columbia "was equipped with the necessary institutions and staff for that purpose"."

The Burnshine decision reflects several of the problems which the American courts experienced with the "reasonable classification" test. It does not even appear, for example, that Mr. Justice Martland considered that the classification had to have "some reasonable basis". Burnshine was required to establish "compelling reasons" "that the classification was not related to the purpose. That is, Martland's test was something less than even the diluted "minimum rationality" test. Furthermore, Martland determined the legislative purpose of section 150 simply by quoting from earlier judgments. Had he employed the various techniques of statutory interpretation and considered section 150 in its total internal and external context, ${ }^{100}$ he might very well have come to a different conclusion. In addition, by defining the statutory purpose as the reform of young offenders Martland in effect disposed of the question whether the classification was reasonably related to the statutory purpose. But what appeared to Martland to be a reasonable, beneficial purpose might not actually be so on closer examination. Finally, because his choice of legislative purpose determined the reasonableness of the classiffcation, the "reasonable classification" test was simply tautological. Thus, consistent with utilitarian theory, the community welfare as reflected in the statutory purpose created and conditioned the very existence of equality before the law. Equality before the law can hardly be said to have been taken seriously.

\section{(e) Canadian Legislative Enactment of the "Reasonable} Classification" Test

Canadian legislatures have also adopted the "reasonable classification" approach towards human rights. Section 4(4) of the Ontario Human Rights Code, ${ }^{101}$ for example, expressly permits discrimination on the basis of race, colour, creed, nationality, ancestry or place of origin where it is "a reasonable occupational qualification" 100 in an "exclusively religious, philanthropic, educational, fraternal or social organization that is not operated for private profit" or in "any organization that is operated primarily to foster the welfare of a religious or ethnic group and that is not operated for private profit". In 1974 the Ontario legislature amended the Code to permit discrimination where age, sex or marital status was a "bona fide" occupational qualification. ${ }^{103}$

Id. at 60, 25 C.R.N.S. at 280.

Id., 25 C.R.N.S. at 281 .

100 See generally Attorney-General v. Prince Ernest Augustus of Hanover, [1957] A.C. 436, [1957] 2 W.L.R. 1 (1956); Director of Public Prosecutions v. Schildkamp, [1971] A.C. 1, [1969] 3 All E.R. 1640, [1970] 2 W.L.R. 279.

101 R.S.O. 1970, c. 318.

102 Emphasis added.

100 S.0. 1974 c. 73, ร 2. 
Similarly, section 3 of the New Brunswick Human Rights Code ${ }^{104}$ in its first three subsections forbids discrimination on many different grounds. However, subsection (5) enacts:

Notwithstanding subsections (1), (2), (3) and (4), a limitation, specifcation or preference on the basis of race, colour, religion, national origin, ancestry, place of origin, age, marital status or sex shall be permitted if such limitatioh, specification or preference is based upon a bona flde occupational qualification as determined by the [New Brunswick Human Rights] Commission.

The New Brunswick Code permits "bona fide" diserimination with respect to the occupancy of any commercial or dwelling unit, the accommodations, services or facilities available in any place to which the public is customarily admitted, ${ }^{108}$ and the publication or display of any notice, sign, emblem or other representation. ${ }^{107}$ Indeed, section 7 (2) goes so far as to permit discrimination on the above grounds whete any statute restricts membership in a professional association, business or trade association to Canadian citizens or British subjects.

The Canadian Human Rights Bill, ${ }^{\text {tot }}$ which received first reading on July 21, 1975, also adopts the "reasonable classification" approach. Section $10(2)$ enacts that "it is not a discriminatory practice to pay to male and female employees different wages if the difference is based on a reasonable factor, other than sex, trat justifies the difference". ${ }^{\text {10 }}$ Section 11 provides:

It is not a discriminatory practice if

(a) any refusal, exclusion, expulsion, suspension, limitation, specification or preference in relation to any employment is based on a

'bona fide' occupational requirement.

Section 12(2) then gives the Canadian Human Rights Commission authority to determine whether any "program, plan or arrangement" is reasonably justifiable. Such a determination is binding. A reasonably justifiable program is one that appears to have benevolent purposes. More precisely, it is

a special program, plan or arrangement designed to prevent disadvantages that are likely to be suffered by, or to eliminate or reduce disadvantages that are suffered by, any group of individuals when those disadvantages would be or are based on or related to the race, national or ethnic origin, colour, religion, age, sex or marital status of members of that group . . . .

Finally, even the major proposal for an entrenched Bill of Rights known as the Victoria Charter expressly permits "limitations on the exercise of the fundamental freedoms as are reasonably justifiable in a democratic society

${ }^{100}$ R.S.N.B. 1973 , c. H-11.

1008 is $4(4)$.

10 $5(2)$

$10056(3)$.

${ }^{100}$ Bill c-72, 30th Parl., 1st Sess. (1974-75).

tom Emphasis added. in the interests of public safety, order, health or morals, of national security, or of the rights and freedoms of others ..."."

Each of these legislative enactments of "human rights" is subject to the same limitations already encountered in the American courts. "Indeed, our protection of equality is even weaker than the American "reasonable classification" approach, because the Canadian judiciary in its conspicuous reverence for legislative supremacy will leave untouched the express legislative enactment of "bona fide" discrimination. Even "compelling reasons" will not apparently overrule a "bona fide" discrimination. Furthermore, "benevolence" itself depends on the social or economic values of a particular segment of a particular generation of a particular society. Have the ruling classes in feudal and slave societies not pursued discriminatory practices at least in part from benevolent motives? Finally, in the case of the Victoria Charter, one must wonder whether the freedoms entrenched are fundamental in any real sense. When could the Canadian state not reasonably and justifiably limit the freedoms? To suggest, as does Professor Tarnopolsky, ${ }^{112}$ that the limitations must be consistent with a liberal-democratic society simply begs the question.

\section{A Democratic Approach Towards Equaltty Before The Law}

Bentham reafized that the most outrageous inequalities were consistent with equality defined as the equal administration of the law. Laws could be empty of moral content and still be impartially administered. But Bentham's attempt to put moral content into the law with his notion of the greatest happiness of the greatest number would still be of no use to criticize,

${ }^{110}$ Article 3 of the Charter, approved by the federal and nine provincial governments at the Constitutional Conference in Victorio, June 1971 (emphasis added). Articles 1 to 3 read:

1. It is hereby recognized and declared that in Canada every person has the following fundamental freedoms: freedom of thought, conscience and religion; freedom of opinion and expression and freedom of peaceful assembly and association, and all laws shall be construed and applied so as not to abrogate or abridge any such freedom.

2. No law of the Parliament of Canada or the Legislatures of the Provinees shall abrogate or abridge any of the fundamental freedoms herein recognized and declared.

3. Nothing in this Part shall be construed as preventing such limitations on the exercise of the fundamental freedoms as are reasonably justifiable in a democratic society in the interests of public safety, order, health or morals, of national security, or of the rights and freedoms of others, whether imposed by the Parliament of Canada or the Legislature of a Province, within the limits of their respective legislative powers, or by the construction or application of any Iaw.

Note also the American Civil Rights Act, 42 U.S.C. \& 2000 e-2(c) (1964), which provides that religion, sex and national origin are legitimate criteria in hiring practices where they are "a bona fide occupational qualification reasonably necessary to the normal operation of that particular business or enterprise".

iIt W. TARnopolsky, The CANADLAN Bill OF Rughts, supta note 55, at 316. 
for example, a slave society, because an impartially administered law need not benefit the minority of slaves. The greatest happiness of the greatest number, for example, could dictate the internment of Canadians of Japanese ancestry or the compulsory settlement of immigrants in specified geographic areas of the country. Such laws could be impartially administered and thereby satisfy both branches of the utilitarian theory of equality before the law. Because utilitarian theory subordinates liberty and equality to the welfare of the majority, individual rights are not really rights at all. One could more accurately describe them as "social concessions". ${ }^{118}$ Whatever rights the individual has he has by virtue of the state's own self-imposed limitations.

\section{A. The Democratic Alternative}

If one wishes to take equality and liberty seriously, one must begin from a very different perspective. Whereas the utilitarian assumes that the ultimate norm is the community's welfare, the democrat starts from the assumption that the human personality is of intrinsic worth, of absolute value, and, therefore, that each personality is equally worthy of human respect and human dignity. ${ }^{11 s}$ The latter norm arises because one is a member of the

${ }^{113}$ I take this term from the very perceptive study of liberalism by J. HaLLoweIL, THE DECLINE OF LIBERALISM AS AN IDEOLOOY 73 (1971).

${ }^{113}$ C. B. MACPHERSON, THE ReAL Worud OF DEMOCruCY $36-37$ (1965), points out that Marx as well as some liberal-democratic theorists start with this common assumption. Marr's pre-1848 writings certainly show this perspective; see his manuscripts reprinted in E. FromM, MARX's CONCEPT OF MAN 93-168 (1963). See also scripts reprinted in E. FromM, MARx's Con

The liberal-democratic theorists I bave in mind are Kant, T. H. Green and Sir Ernest Barker. For example, after dealing with the differences amongst the many claimants for liberty, Barker wrote in his RefLEcTIONS ON GOVERNMENT 15-16 (1966): that

In spite of these differences-and they are deep-we cannot but feel that there must be some single and ultimate claimant for liberty, and some single and essential liberty which that ultimate claimant demands. What is this ultimate claimant, and what is this essential liberty? We may make an assumption, and we shall find an answer. The assumption is that in our human world, and under God, the individual personality of man alone has human world, and under God, the individual personality of man alone has
intrinsic and ultimate worth, and having also the capacity of development has also an intrinsic and ultimate claim to the essential condition of its development. Liberty will then be that essential condition; and the essence of liberty will be that it is a condition, or status, or quality, which individual personality must possess in order that it may translate itself from what it is to what it has the capacity of becoming.

One might even interpret Mill's On Liberty as starting from the premise of human dignity, although this is debatable for the reasons already expressed (see text between notes 53 and 59). See also G. HIMMELFarb, ON LIBERTY AND LIBERALISM (1974). Note particularly ch. 3 of On Liberty, supra note 45, at 304 . At one point Mill described human nature not as "a machine to be built after a model, and set to do exactly the work prescribed for it, but a tree, which requires to grow and develop itself on all sides, according to the tendency of the inward forces which make it a living thing". Id. at 308 .

I am indebted to Professor C. B. Macpherson for bringing to the fore the antidemocratic aspects of utilitarian theory in his lectures and writings. See especially C. B. Macpherson, Democratic Theory: Essays in Retrueval (1973), and The "gens humana", not because one is a citizen of the sovereign secular state, which, after all, is a relatively recent European idea. "14

More precisely, as Maurice Cranston and Professor Raphael have pointed out, ${ }^{113}$ the state does not give us fundamental freedoms. The state merely metaphorically acknowledges their existence, because we already have them as members of the human race. Similarly, the state may not take fundamental freedoms away on the pretext that such freedoms must be earned. They are the rights "of man", not "of the citizen". They are held independently of statute, judicial decision or custom. They are held independently of the individual's "worth to society".

As rights "of man", they are owed to all persons equally and not just to some. Though differing in ability and environment, all persons share a common humanness. For this reason equality before the law must mean something more than just formal equality or even equality in a majoritarian sense. Equality before the law requires an interpretation that accords due respect for human dignity in all persons. ${ }^{\text {no }}$

In the first place, respect for human dignity would proscribe legislative classifications according to race, sex, national origin, colour and religion. For, if the majority decides to apply a law to, say, one racial group, that law violates the members' human dignity vis-a-vis persons outside the group. That is, the law does not treat all persons "as persons" and "as humans", and the latter notion exists independently of the law. This first type of treatment, however, does not preclude an oppressive, tyrannical government: such a government could take away all liberty from all persons equally without regard to race, sex or whatever. Thus, respect for human dignity, as a second requirement, precludes interference with any person's life, liberty, or self-expression.

Real. Wortd of Democrncy, supra note 113. See also Professor Peter Russeil's important essay A Democratic Approach to Civil Liberties, $19 \mathrm{U}$. Torosto LJ. 109 (1969). Both RusseIl and Macpherson, however, appear to focus on the notion of "the dovelopment of the individual" rather than "human dignity" as the central normative assumption of democratic theory. Professor Russell in particular appears to come to very different conclusions with respect to the judicial function in interpreting the Canadian Bill of Rights.

${ }^{114}$ The contemporary system of organizing international relations according to secular states originated in Renaissance Italy. See A BozEMn, Poincs TURE IN INTERNATIONAL HISTORY ch. 13 (1960); F. HINSLEY, Power AND THE PURSUTT of Peace 163-68 (1967); J. Burckhatet, 1 The Civilization of the Renassance IN ITALY (S. Middlemote transl. 1958).

${ }^{113}$ Raphael, Human Rights, Old and New, in Politicat THEORY AND THE Rights of MaN 54 (D. Raphael ed. 1967); Cranston, Human Rights: A Reply to Professor Raphael, id. at 95; Raphael, The Righis of Man and the Rights of the Citizen, id. at
101.

116 The notion of human dignity bas been discussed in recent philosophical journals. See, e.g., Bay, Foundations of the Liberal Make-Believe, 14 INOUIRY 213 (1971); Connolly, Comment on Bay, 14 INQurRY 237 (1971); Blackstone, Human Rights and Human Dignity, 9 PHitosopHY Forum 3 (1971); Munster, A Critique of Blackstone's Human Rights and Human Dignity, 9 Phlosophy ForUm 65 (1971); Blackstone, Equality and Human Rights, 52 MONIST 616 (1968). 
Why are the latter freedoms of life, liberty and self-expression so necessary to the fulfilment of respect for human dignity? In the first place, underlying respect for human dignity is the notion that the individual himself-not the community or state-is the valuator of his own ideas and behaviour. Thus, notwithstanding Isaiah Berlin, ${ }^{11}$ humanly imposed impediments include not simply intentional physical coercion but also restrictions upon the individual's ability to express himself by speaking, writing, and assembling. Secondly, we respect a person's human dignity because of his "daimon", "the ideal possibility" within him. "1" The notion of human dignity is a normative rather than an empirical idea: each person is always a potentiality in the process of becoming. One obvious essential condition precedent for respect for human dignity, therefore, is respect for life itself; for with death dies all potentiality for development in the human world. Similarly, without freedom of speech, religion or assembly one cannot express oneself. Without expressing oneself one cannot develop emotionally, mentally or psychically. For this reason any limitation upon one's right to speak, to pursue religious practices, to write, or to assemble, fundamentally inhibits the attainment of human dignity. That is, to speak of human dignity without also speaking of fundamental freedoms of life, speech, religion and assembly is to talk of an abstraction, emptied of moral content.

Several problems arise out of this approach toward civil liberties. First, Isaiah Berlin has contended that this approach has provided despots with the opportunity to oppress in the name of the interest of the "true" or "real" self." ". Admittedly, the notion of a "true self" could lead to tyranny. But Berlin's analysis conceives the self to be an actuality, whereas the "self" I am talking about is a potentiality whose nature our fallibility prevents us from knowing. The "self" as a potentiality necessitates an immanent, not an imposed, freedom. In this way the basis of freedom cannot logically lead to tyranny, because the "self" being respected is always the "daimon" within us.

A second problem, which Kai Nielsen has raised, ${ }^{20}$ is that neither argument nor evidence can demonstrate that all persons are equal because of their common humanity. The latter proposition merely reflects our morality; there is no proof that it is a superior morality. Therefore, ac-

"11 Berlin, in his Two Concepts of Liberty, in Foun EsshYs ON LTERRTY 118, at 125 (1969), distinguishes "liberal", individual freedom" from social and economic freedom. He defines coereion as "the dellberate interference of other human beings within the area in which I could otherwise act". Id. at 122; emphasis added. Mere economic or other incapacity is not lack of political freedom. Human beings lack political freedom only if they are intentionally prevented from attaining a goal. "The fundamental sense of freedom is freedom from chains, from imprisonment, from enstavement by others. The rest is extension of this sense, or else metaphor." Berlin, Introduction to Four EssAYs ON LTEERTY, id, at lvi.

11" Norton \& Norton, From Law to Love: Social Order as Self-Realization, $6 \mathrm{~J}$. VALUE INOULIY 91. at 92 (1972).

119 Berlin, Two Concepts of Liberty, supra note 117, at 133.

12* Nielsen, Scepticism and Human Righrs, 52 MoNIsT 573 (1968). cording to Nielsen, we cannot justifiably say that there are universal human rights. My argument, however, is that if one professes to be a democrat one must start from the norm-admittedly arbitrary-of respect for human dignity, rather than with the equally empirically non-provable norm of the greatest bappiness of the greatest number. ${ }^{121}$ If the community compromises the fundamental rights and freedoms derived from the norm of human dignity, then it does so in the name of some anti-democratic value.

Thirdly, how does one come to terms with our seventeenth-century notion of legislative supremacy and its political counterpart, "majority rule"? For one thing Bachrach, ${ }^{\text {ws }}$ Schattschneider ${ }^{12}$ and other political theorists ${ }^{12}$ have forcefully argued that classical democratic theory began with the goal of human dignity rather than majority rule. Classical democratic theory advocated majority rule, not as an end in itself, but because it enlarged the scope for individual experience and self-respect. Majority rule was only one means of achieving that democratic goal.

Furthermore, one can adequately face the issue of legislative supremacy only be examining the authority that underlies an act of Parliament as a source of law. If one suggests that the validity of an act depends upon whether Parliament has followed the proper "manner and form" requirements, the question still remains as to what gives these requirements their authority. One can examine the statutory, customary or common law basis of "manner and form" requirements only so far; beyond lies a fundamental political value or "Grundnorm" rather than a legal rule as understood in the traditional Austinian sense. ${ }^{125}$ Legislative supremacy has not always been the fundamental political value in the Anglo-Saxon constitution. And it is submitted that if one is a democrat, then human dignity should replace "the greatest happiness of the greatest number" as the fundamental political value underlying our constitution.

This is not to suggest that legislative supremacy has no place in our constitution. Quite the contrary. I shall argue below that, by enacting the Canadian Bill of Rights in the way it has, Parliament has expressly directed our courts to define the nature and scope of our rights and freedoms from a democratic rather than a utilitarian perspective. If the courts do not face this challenge, they violate the notion of legislative supremacy itself.

${ }^{213}$ Indeed, even Bentham admitted that one could not empirically prove the validity of the utilitarian norm of the "greatest happiness of the greatest number":

Is it susceptible of any direct proof? It should seem not: for that which is used to prove every thing else, cannot itself be proved: a chain of proofs must have their commencement somewhere. To give such proof is as impossible as it is needless.

(J. BENTHAM, AN INTRODUCtion, supra note 31, at Ch. 1, para. 11.).

${ }^{213}$ See P. BACHRACH, The Theory OF Democratic Elinsm (1969).

129 Cf. E. Schuttschinemer, THe Semisovereion People (1960).

w4 See Walker, A Critique of the Elitist Theory of Democracy, 60 AM. PoL. Scl. REv. 285 (1966); B. HOLDEN, THE NATURe OF DEMOCRACY (1974).

22; Gray, The Sovereignty of Parliament Tars of Legal Soverelgnty, [1955] CAMB. L.J. 172; Gray, The Sovereignty of Parliament Today, 10 U. ToRonto L.J. 54 (1953);
Middleton, Sovereignty in Theory and Practice, 64 JURID. REv. 135 (1952). 


\section{B. Some Legal Implications of the Democratic Norm}

\section{The "Suspect Doctrine": A Step in the Right Direction}

Because of the weaknesses of the "reasonable classification" test for defining "equal protection", the U.S. Supreme Court developed what came to be known as the "suspect doctrine". ${ }^{126}$ The doctrine, which received its first judicial acknowledgement in Stone's famous footnote in the 1938 Caroline Products case, ${ }^{137}$ had two branches. The two branches corresponded to the two types of mode of treatment raised above. First, the Court immediately suspected any classification the basis of which was some trait which a person was powerless to change, as, for example, his race. ${ }^{120}$ Secondly, a classification was immediately suspect where it infringed a first amendment freedom. "The Court labelled the two branches "invidious discrimination" and "fundamental interests".

${ }^{138}$ One should bear in mind that during the past months the U.S. Supreme Court has used neither the "reasonable classification" test nor the "suspect" doctrine whole heartedly. Rather, the Burger Court seems to be adopting a third, "means-oriented" approach which questions whether legislative classifications bear a substantial relationship, as a question of fact, to articulated legislative purposes. The newer approach seems to be half-way between the "reasonable classification" and "suspect" tests. Because it accepts articulated legislative purposes as a given, the new test suffers from the same political criticisms raised wilh respect to the "reasonable classification" test For recent examples of the application of the new test, see Reed v. Reed, 404 U.S. 71 92 S.Ct. 251 (1971): Frontiero v. Richardson, 411 U.S. 677, 93 S.CL 1764 (1973) Eisenstadt v Baird, 405 US. 438, 92 S.C. 1029 (1972): and most importantly San Elscnstad Anlonio For leading articles elaborating the "means-oriented approach, see Gunther, Foreword In Search of Evolving Doctrine on a Changing Courl: A Model for a Newer Equal Protection, 86 HARv. L. REv. 1 (1972); The Irrebuttable Presumption Doctrine in the Supreme Court, 87 Harv. L Rev. 1534 (1974); Phillips, Irrebutiable Presumptions An Illusory Analysis, 27 STAN. L. REv. 449 (1975); Kwasnick, A Question of Balance. Staturory Classifications Under the Equal Protection Clause, 26 StaN. L. Rev. 155 (1973).

wi United States v. Caroline Prods. Co., 304 U.S. 144, at 152-53 n. 4, 58 S.CL. 778 , at $783-84$ n. 4 (1938):

There may be narrower scope for operation of the presumption of constitutionality when legislation appears on its face to be within a specific prohibition of the Constitution, such as those of the first ten Amendments, which are deemed equally specific when held to be embraced within the Fourteenth ....

It is unnecessary to consider now whether legislation which restricts those political processes which can ordinarily be expected to bring about repeal of undesirable legislation, is to be subjected to more exacting judicial scrutiny under the general probibitions of the Fourteenh Amendment than scrutiny under the geseral probibitions of the Fourteenth Anendment than we enquire whether similar considerations enter into the review of statutes directed at particular religious . . . or national . . . or racial minorities ... whether prejudice against discrete and insular minorities may be a special condition, which tends seriously to curtail the operation of those political processes ordinarily to be relied upon to protect minorities, and which may call for a correspondingly more searching judicial inquiry ...

${ }^{22}$ For an elaboration of this first branch, see Michelman, supra note 69, at 33-39; Tussman \& tenBroek, supra note 65 , at $353-56$.

120 For an elaboration of this branch, see Goodpaster, supra note 80 , at $488-92$
Any "suspect" classification had several legal implications. First, the onus of proof shifted from the petitioner to the state. Secondly, the Court scrutinized the relationship between the classification and the legislative purpose far more closely than the "reasonable classification" test had demanded. It was not enough for the state to establish that the classification was "rationally" or even "reasonably" related to the legislative purpose; the classification had to be a "necessary" means to achieve the purpose. Similarly, the Court had to assure itself that the legislature could not have employed less stringent alternatives. Thirdly, the "necessary" means could be over- or under-inclusive only if "compelling governmental interests" required it, as supposedly was the case in the internment of the Japanese Americans. ${ }^{191}$

Probabiy the most important consequence of the suspect doctrine was that the U.S. courts were unwilling to limit themselves to the face of the statute in their assessment of what constituted the purpose of the enactment. As Tussman and tenBroek state, 12 the suspect doctrine demanded a purity of legislative motive, free from hate, prejudice, vengeance, hostility, favouritism or partiality. Similarly, the courts went beyond the face of the statute by examining the consequences of implementing the allegedly inequitable classification.

The 1956 Supreme Court decision of Griffin ${ }^{\text {tas }}$ reflects the difference between the "reasonable classification" and "suspect" tests. Griffin had sought a free transcript of his trial in order to prepare the required documents for his appeal. Griffin alleged that, as he was a very poor person, the state should provide him with a free transcript so that he would be treated equally with wealthy persons. A "reasonable classification" analysis would have stopped there: the statutory rule was "prima facie" valid, "practicalities" necessitated a transcript fee, there were always going to be some inequalities, and the like. But the Griffin court went further and scrutinized the "effect" of a refusal to grant a free transcript to an indigent person. The Supreme Court perceived in that refusal an "unarticulated classification" which had the effect of restricting the right to appeal to wealthy persons. In Mr. Justice Black's judgment, "[t]here is no meaningful distinction between a rule which would deny the poor the right to defend themselves in a trial court and one which effectively denies the poor an

${ }^{190}$ McLaughlin v. Florida, 379 U.S. 184, at 196, 85 S.Ct. 283, at 290 (1964).

in In Korematsu, supra note 86, at 216, 65 S.Ct. at 194, the Supreme Court used the term "pressing public necessity" to justify legislative over- and under-inclusiveness

14 Tussman \& tenBrock, supra note 65, at 358 . In Korematsu, supra note 86, at 223, 65 S.CL at 197, for example, the Supreme Court found that the detention measures against American citizens of Japanese heritage were motivated not out of "hostility" or "racial prejudice", but because of a feared invasion by the Japanese Empire and the "presence of an unascertained number of disloyal [Japanese Americans]". Id. at 218, $65 \mathrm{S.Cl}$ at 195.

${ }^{133}$ Griffin v. Illinois, 351 U.S. 12, 76 S.Ct. 585 (1956). 
adequate appellate review accorded to all who have money enough to pay the costs in advance". ${ }^{\text {st }}$ Mr. Justice Black went even further:

Statistics show that a substantial proportion of criminal convictions are reversed by state appellate courts. Thus to deny adequate review to the poor means that many of them may lose their life, liberty or property because of unjust convictions which appellate courts would set aside. ${ }^{\text {tat }}$

The classification of indigent persons bore "no relation to a rational policy of criminal appeal".

The Griffin decision reflects both aspects of the suspect doctrine. On the one hand, the case involved what some have suggested is an inherently discriminatory classification (indigent persons), much as race ${ }^{137}$ and alienage ' ${ }^{\prime \prime \prime}$ have been held to be. On the other hand, the classification related to the fundamental interest of the right to appeal. Other interests held to be fundamental are the right to procreate, ${ }^{130}$ the right to interstate travel ${ }^{140}$ and the right to vote. 14

What is most objectionable in the suspect doctrine is the apparent judicial arbitrariness of ascertaining which classifications are inherently discriminatory and which interests are fundamental ones. The courts have given three reasons for making the former determination. First, race, wealth, creed, colour, sex and illegitimacy of birth can bear no possible relevance to the purpose of any legislative enactment. 10 Secondly, one has

19 Id. at 18, $76 \mathrm{S.CL}$ at 590 (emphasis added).

128 Id. at $18-19,76 \mathrm{S.CL}$ at 590 .

in Id, at 22, 76 S.Ct. at 592 (Frankfurter J.)

${ }_{19}$ By 1944, the U.S. Supreme Court could state that "all legal restrictions which curtail the civil rights of a single racial group are immediately suspect". Korematsu, supra note 86, at 216, 65 S.Ct at 194. See also McLaughlin v. Florida, supra note 130, at $191-92,194,85$ S.Ct. at $288-90$.

'19 In re Griffiths, 413 U.S. 717, 93 S.Ct. 2851 (1973); Sugarman v. Dougall, 413 U.S. 634, 93 S.Ct. 2842 (1973); Graham v. Richardson, 403 U.S. 365, 91 S.Ct. 1848 (1971). See also Levy v. Louisiane, 391 U.S. 68, 88 S.Ct. 1509 (1968), where Douglas J., speaking for the majority, held that a Louisiana statute "invidiously discriminated" when it allowed legitimate, but not illegitimate, children to recover damages for the wrongful death of their mother.

It Skinner v. Othahoma, 316 U.S. 535, 62 S.Ct. 1110 (1942).

1w Skapiro v. Thompson, 394 U.S. 618,89 S.Ct. 1322 (1969). Williams v. Rhodes, 393 U.S. 23, 89 S.Ct. 5 (1968).

${ }_{14}$ In Harper, id. at $668,86 \mathrm{~S} . \mathrm{Cl}$ at 1082 , Douglas J. said: "Wealth, like race, creed, or color, is not germane to one's ability to participate intelligently in the electoral process." And in Levy, supra note 138, at 72, 88 S.Ct. at 1511, he justified the labelling of illegitimacy as "invidious" on the ground that "Ilegitimacy or illegitimacy of birth has no relation to the nature of the wrong allegedly inflicted on the mother". Similarly, in Frontiero v. Richardson, supre note 126, at 686-87, 93 S.CL. at 1770, Bimilarly, in Frontero v. Richardson, supre note 126 , at

what differentiates sex from such non-suspect statuses as intelligence or physical disability, and aligns it with the recognized suspect criteria, is that the sex characteristic frequently bears no relation to ability to perform or contribute to society. As a result, statutory distinctions between the sexes often have the effect of invidiously relegating the entire class of females to inferior legal status without regard to the actual capabilities of its individual members. such traits from birth: they are immutable. ${ }^{10}$ Thirdly, some courts have reasoned that certain traits are inherently discriminatory because members possessing the traits have been historically oppressed. ' these criteria may conflict with the second or third, is As a consequence the courts' approach has been ad hoc; sometimes the traditional "reasonable classification" approach is taken, sometimes the "suspect doctrine" is ap-
plied. "a

Even more uncertainty arises in trying to find appropriate criteria for distinguishing "fundamental interests" from "non-fundamental" ones. In Skinner, ${ }^{147}$ Mr. Justice Douglas considered marriage and procreation "one of the basic civil rights of man", "fundamental to the very existence and survival of the race". In Shapiro, "Mr. Justice Brennan held that the right to travel was fundamental, as arising out of "the nature of our Federal Union and our constitutional concepts of personal liberty". In Griffin, ${ }^{101}$ Mr. Justice Frankfurter held that to limit the effective right to appeal a criminal case to only those who could afford to do so violated "the deepest presuppositions of our society". And Mr. Justice Harlan in dissent believed the basis of the majority decision in Griffin was "simply an unarticulate conclusion that [the refusal to provide a free transcript] violates "fundamental fairness" ". "so None of these judgments, however, sets out a means

tw Since a member of a suspect class such as one based on "national origin" or "sex" can do nothing to escape from his or her status, he or she should not have to bear individual responsibility for the mischicf against which the statute is directed. The state should not penalize the individual for possessing such traits. See Weber v. Aetna Casualty \& Surety Co., 406 U.S. 164, at 175, 92 S.Ct. 1400, at 1407 (1972) (Powell J.); Frontiero v. Richardson, supra note 126, at 686, 93 S.Ct. at 1770 Brennan J.).

14 Brown v. Bd. of Education, 347 U.S. 483, 74 S.CL. 686 (1954); Frontiero v. Richardson, supra note 126.

${ }^{143}$ For example, several decisions have held that alienage is a surspect category (see note 138, supra). If one chooses the first justificatory eriterion, can it be said that alienage will never bear a relation to a permissible statutory purpose of a benevolent nature? If one chooses the second, can it be said that alienage is an inmutable trait? With respect to the third criterion, can one say that all immigrants have historically been subjected to negative discriminatory treatment?

14 In the Griffiths case, supra note 138, at 730, $93 \mathrm{S.Ct}$ at 2859 , Burger C.J. in dissent criticized the majority's "casual" resort to "the code phrase" of "suspect doctrine" in recent years. The phrase "tends to stop analysis while appearing to sugest an analytical process". And in Sugarman v. Dougall, supra note 138, at 649-50, 93 S.CL at 2861 , Rehnquist J., also dissenting, stressed that

there is no language ... nor any historical evidence as to the intent of the Framers [of the Fourteenth Amendment], which would suggest to the slightest degree that it was intended to render alienage a "suspect" classiffcation, that it was designed in any way to protect "discrete and insular minorities" other than racial minorities, or that it would in any way justify the result reached by the Court [rendering unconstitutional a New York statute which provided that only American citizens could hold permanent positions in the competitive class of the state civil service] . . .

it" Skinner v. Oklahoma, supra note 139 , at 541,62 S.Ct at 113 .

14 Shapiro v. Thompson, supra note 140, at 629, 89 S.CL at 1392.

${ }^{140}$ Griffin v. Illinois, supra note 133, at 22, 76 S.Ct. at 592.

190 Id. at 36,76 S.Ct. at 598. 
of determining "basic civil rights", the "constitutional concepts of personal liberty", or the "deepest presuppositions" of society.

The notion of respect for human dignity does provide an articulated standard for determining an "inherently discriminatory" classification and the "fundamentalness" of a right. Classiffcations that discriminate on the basis of race, national origin, colour, religion or sex violate the human dignity of the members of that class. A fundamental right, under this conception, would be one that is an essential condition for the fulfilment of the democratic norm of human dignity.

\section{The Canadian Bill of Rights}

As Chief Justice Laskin has noted, ${ }^{131}$ the uncertainty of U.S. Courts in labelling "inherently suspect" categories and rights does not exist to such a great extent in Canada. The Canadian Bill of Rights gives us some guidance. In section 1 of the Bill of Rights, the classifications of race, national origin, colour, religion and sex are enumerated as being inherently discriminatory. Parliament in recognizing such freedoms as freedom of speech, assembly and religion was acknowledging that these are fundamental conditions for the full development of the spontaneous, fully-integrated, total self. This is not to say that there may not be other, possibly more significant conditions. But these are a start and call for a new judicial outlook on the meaning and scope of equality before the law.

In several places the Canadian Bill of Rights indicates Parliament's intention that the courts should interpret the Bill from a democratic rather than a utilitarian perspective. To begin with, the long title, section 1 and the preamble all describe the rights as human rights and the freedoms as fundamental ones. The words "human" and "fundamental" must have some meaning. We have already seen that each person has a human right by virtue of being a member of the human race, not a citizen of the state. By describing the rights as human rights, Parliament was admitting that the state and its agent-the courts-could not give or take away these rights as if they were social concessions. In the same vein, by describing the freedoms as fundamental, Parliament could hardly have intended that the court should define them by reference to the utilitarian emphasis on the community interest. Quite the contrary. Parliament has said that the freedoms are fundamental. All judicial analysis, therefore, must start from the primacy of the freedoms rather than from the primacy of the "greatest happiness of the greatest number".

This construction of the Bill is reinforced by the fact that Parliament admitted in the long title, the preamble and section 1 that it was not creating freedoms. Rather it was recognizing their existence and fundamentalness (possibly for the first time in some cases). For the rights and freedoms

${ }^{151}$ Attorney General of Canada v. Lavell, supra note 23, at 1386, 23 C.R.N.S. at 226, 38 D.L.R. (3d) at 510. existed independently of Parliament and the courts. Furthermore, the preamble provides that these rights and freedoms "are derived" from principles which include, among others, "the dignity and worth of the human person". In addition, one should note the absolute character of the verbs: the rights anid freedoms have existed and "shall continue to exist"; and every law of Canada "shall be construed and applied so as not to abrogate, abridge or infringe these rights and freedoms". Finally, Parliament enacted that unless a future Parliament expressly declared that an act was to operate notwithstanding the Canadian Bill of Rights, the nature and scope of the rights and freedoms listed in section 1 were unlimited. That is, the courts had no authority to limit the rights and freedoms when they (the courts) deemed that to do so was reasonably justifiable in the light of a statutory purpose. In this way, the judicial invention of "reasonable classification" is contrary to what Parliament intended when it enacted the Canadian Bill of Rights.

The point is further substantiated when one examines the Bill in the light of other statutes on the subject of human rights. As already noted, the Ontario and New Brunswick Human Rights Codes, the draft Canadian Human Rights Code, the Victoria Charter and the American Civil Rights Act, 1964, expressly contemplate a judicial role in restricting human rights when the courts deem it reasonably justifiable to do so. ${ }^{\text {ss }}$. The fact that the Canadian Parliament phrased the rights and freedoms in the Bill in such absolute terms without reference to "reasonable justifiability" reflects Parliament's intention that it alone and not the courts could determine whether rights and freedoms were intended to be justifiably restricted.

\section{The Applicability of a Democratic Approach in Canada}

The construction of the Canadian Bill of Rights from a democratic point of view has at least three major implications for judicial analysis.

In the first place, we have seen that respect for human dignity translates into two legal principles. ${ }^{18 s}$ First, the norm proscribes certain legislative classifications which violate a person's human dignity vis-a-vis persons outside the class. Section 1 of the Canadian Bill of Rights suggests five such categories: race, sex, national origin, colour and religion. Secondly, the norm precludes interference with a person's life, liberty and self-expression (through speech, religion, assembly and the press). These rights and freedoms were what Parliament considered essential or fundamental for the full development of the individual.

The second implication is that each of these two principles may operate independently of the other in their effect on legislation or the common law. The first principle might be satisfjed under an oppressive, tyrannical government. That is, the state could do away with the freedoms of life, liberty and self-expression for everyone without discrimination on the basis of race,

\footnotetext{
139 See text between notes 101 and 110.
13 See text between notes 113 and 118 .
} 
sex, national origin, colour or religion. Similarly, the freedom of selfexpression does not logically preclude the possibility of a slave society. That is, a society with freedom of speech, religion, assembly and the press could still have social and economic legislation which discriminates on the basis of race, sex, national origin and colour. But both tyranny and slavery are quite alien to any society which professes to be based upon the notion of respect for human dignity. A democratic approach towards equality before the law, therefore, must scrutinize legislation and common law principles on both fronts.

The third implication relates to the technique of judicial analysis. The reasonable classification test, we have seen, hinged upon statutory purpose. As in the case of Griffin, ${ }^{14}$ however, our courts must also be prepared to examine the logical and empirical consequences of applying a statute or common law principle. Only by doing so will they be able to perceive the real classifications and fundamental freedoms at stake. This technique of judicial analysis is not a new one in Canadian civil liberties cases. It was Mr. Justice Rand's tool of analysis in Roncarelli v. Duplessis, ${ }^{\text {ws }}$ and, indeed, several other important civil liberties judgments reflect how the courts have scrutinized the effects upon fundamental freedoms of applying various statutes. ${ }^{\text {at }}$

And how would one apply these three implications to such Canadian cases as Lavell ${ }^{\text {t37 }}$ and Burnshine? ${ }^{130}$ The crucial question in Lavell would not be whether there is "any rational and acceptable policy justification for the discriminatory provision under review". to such a question, of course, assumes that Mrs. Lavell's human right to be treated as a person may be balanced against the community interest as embodied in the Indian Act. As we have seen, such a utilitarian approach does not take equality before the law seriously. Instead, the crucial question is simply whether in its purpose or its effect section 12(1)(b) of the Indian Act discriminates on the basis of sex in Mrs. Lavell's circumstances. Although the purpose of section 12(1) (b) may very well have been a benevolent one (such as to protect tribally structured Indian communities), section 12(1)(b) operates so as to discriminate on the basis of sex. The logical consequence of section

\section{iss Griffin v. Illinois, supra note 133.}

1ss Supra note 18, at 139-41,16 D.L.R. (2d) at 704-706.

260 See Reference Re Alberta Statutes, [1938] S.C.R. 100, [1938] 2 D.L.R. 81; Saumur v. City of Quebec, [1953] 2 S.C.R. 299, [1953] 4 D.L.R. 641 (especially the judgment of Rand J.); Switzman v. Elbling, [1957] S.C.R. 285, 7 D.L.R. (2d) 337 (especially the judgment of Rand J.); Regina v. Beattie, [1967] 2 O.R. 488, 64 D.L.R. (2d) 207 (H.C.) (Hartt J.); Liyanage v. The Queen, [1967] I A.C. 259, at 289-92 [1966] 1 All E.R. 650, at 659-61 (P.C. 1965) (Lord Pearce). See also Robertson The Oveen [1963] S.C. 651,41 D.L R (2d) 485, for possibly the only Candin Bill of Rights case where the Supreme Court looked to the effect of the operation of a statule.

137 Supra note 23.

13s Supra note 2. crucial issue. $12(1)(b)$ is that an Indian male would not lose his Indian status upon his marriage to a non-Indian woman, whereas an Indian woman would lose her Indian status upon her marriage to a non-Indian man. Section 12(1) (b), therefore, is inherently discriminatory, with the result that our courts could allow the section to stand only if Parliament expressly provides that section $12(1)(b)$ is to operate "notwithstanding the Canadian Bill of Rights".

And how would one deal with such a case as Burnshine from a democratic perspective? One would initially consider what possible classifications are at issue in section 150 of the Prisons and Reformatories Act. Age is a relevant category, because males under the apparent age of twenty-two years may be subject to an indeterminate sentence in British Columbia, whereas other males of the same age who commit the same offence in other parts of Canada, other than Ontario, would not be subject to such a sentence. Age, however, is not a category which the Canadian Bill of Rights proscribes as inherently discriminatory. The only other possible classification is sex, because section 150 (c) provides that a B.C. court may impose an indeterminate sentence on a female apparently under the age of twenty-two years when the Lieutenant-Governor of British Columbia has designated a reformatory for such female persons. The effect of the Lieutenant-Governor's omitting to make such a designation would in practice be that females apparently under the age of twenty-two years in B.C. would not be subject to any possible indeterminate sentence, whereas males of the same age in B.C. would be subject to such a sentence. Thus, although section 150 on its face does not necessarily create discrimination on the basis of sex, such may be the effect of its application. Even if this were not so, however, section 150 violates the second branch of the democratic approach toward equality before the law because it interferes with a person's equal right to liberty. The state forces a person to give up his or her equal right to liberty when its officials order him or her to a reformatory for a longer term than that provided for other Canadians under the Criminal Code. For this reason the B.C. courts could give full effect to section 150 only if Parliament confronts the civil liberties issue by prefacing section 150 with a "notwithstanding" clause. ${ }^{\text {160 }}$

But, one might ask, does not this alternative also fall into the "utilitarian trap"? Is not Parliament weighing the community interest against the freedoms and rights of the individual when it attaches a "notwithstanding" clause to a statutory provision? The answer would seem to be that Parliament is so compromising the freedoms and rights. But, it is doing so openly in the name of some value other than the democratic one. My

${ }^{100}$ Ironically (and contrary to what Pigeon J. might hold, considering his judgment in The Queen v. Drybones, supra note 94) this approach is more consistent with parliamentary supremacy than is the "reasonable classification" test. For one thing, it gives more substantive meaning to the words of Parliament in section 2 of the Canadian Bill of Rights. Secondly, it forces Parliament, rather than the courts, to decido when the rights and freedoms in the Bill should be restricted in the name of the "community interest". 
thesis in this respect is simply that if one wishes to profess the democratic ideal, then one can never use the community interest as a "rational and acceptable policy justification" for restricting equality before the law. Only another conflicting fundamental freedom or human right can provide such a justification.

This alternative approach begs at least two further important questions. First, what is the nature and scope of the fundamental freedoms and human rights elaborated in sections 1 and 2 of the Canadian Bill of Rights? And secondly, how should one resolve a conflict between two or more of these freedoms and rights? Although these two very important questions go beyond the immediate scope of this essay, it might suffice to suggest that the democratic as opposed to the utilitarian approach towards civil liberties in Canada at least compels one to raise and to try to deal with these two questions.

\section{Conclusion}

I have attempted to enunciate the political presupposittons underlying the judicial interpretation of equality before the law. Utilitarian theory had two branches. The first involved the notion of the impartial administration and application of the law. The second branch contemplated the limitation of equality when to do so was reasonably justifiable from the community's viewpoint. The Supreme Court of Canada adopted the first branch in the Lavell case. Canadian scholars have urged that our courts adopt the second.

I have argued that the second branch is not the direction our courts should go. From the viewpoint of political theory, the "reasonable classification" approach is founded on utilitarian political presuppositions which are inconsistent with democratic political theory. From the viewpoint of a lawyer, the approach is fraught with uncertainty and arbitrariness. Andmost importantly-from the point of view of the citizen, the test is complex and obscure. It leaves the comprebension and, indeed, the determination of his rights and freedoms to a small elite.

There is an alternative founded on the value of "the dignity and worth of the human person"- to use the very words of the Canadian Bill of Rights. Parliament intended that our courts should construe the Bill from the perspective of this value. The short-lived "suspect doctrine" of the Warren Court also provides some legal implications of this alternative approach.

Unlike the American "suspect doctrine", however, equality before the law is not a prima facie presumption that the courts may overrule if they deem that "compelling state interests" warrant it. Such a presumption would once again bring equality before the law within the traditional utilitarian calculus. If one conceives freedoms as merely presumptions, one thereby admits the conceptual possibility of considering individuals as objects rather than as persons worthy of respect. But if one professes to be a democrat and thereby accepts the basic value of "the dignity and worth of the human person", one must rule out the possibility that individuals may ever be treated as things, having no intrinsic worth or dignity. One must rule out the possibility that "the greatest happiness of the greatest number"or its contemporary equivalents, the "national interest", "public interest" or what you will-may ever outweigh the human rights and fundamental freedoms that derive from the dignity and worth of the human person. Only then can we proudly say that we have taken equality before the law seriously and consistently. 